\title{
Preparation methods of calcium sulphate and urea adduct
}

\author{
${ }^{1}$ Przemysław Malinowski, ${ }^{2}$ Andrzej Biskupski, ${ }^{2}$ Józef Głowiński \\ ${ }^{1}$ The State Higher Vocational School in Nysa, ul. Grodzka 19, 48-300 Nysa, Poland, pmalinowski@pwsz.nysa.pl \\ ${ }^{2}$ Wrocław University of Technology, Institute of Inorganic Technology and Mineral Fertilizers, , Wybrzeże Wyspiańskiego 27, \\ 50-370 Wroctaw, Poland
}

\begin{abstract}
The paper presents the results of laboratory studies on the preparation of calcium sulphate and urea adduct by: grinding, compacting and mixing in the presence of physical water. A method for the measurement of urea conversion into the adduct form, which is based on the difference in solubility of free urea and the adduct bound urea $\mathrm{CaSO}_{4} \cdot 4 \mathrm{CO}\left(\mathrm{NH}_{2}\right)_{2}$ in n-butanol, was developed. Mixing the reagents in the presence of physical water produced the best results. High urea conversion into the adduct form, over $85 \%$, in the prepared samples indicates that this method can be successfully used to get $\mathrm{CaSO}_{4} \cdot 4 \mathrm{CO}\left(\mathrm{NH}_{2}\right)_{2}$ adduct.
\end{abstract}

Keywords: adduct, calcium sulphate, fertilizer, gypsum, phosphogypsum, urea.

Presented at VII Conference Wasteless Technologies and Waste Management in Chemical Industry and Agriculture, Międzyzdroje, 12 - 15 June, 2007.

\section{INTRODUCTION}

Urea forms many intermolecular compounds both with organic and inorganic compounds which are described in literature as: complex compounds, additive complexes, clathrate, inclustion or incorporated compounds, and crystalline adducts ${ }^{1,2}$. Urea reacts with gypsum forming $\mathrm{CaSO}_{4} \cdot 4 \mathrm{CO}\left(\mathrm{NH}_{2}\right)_{2}$ adduct ${ }^{3}$ :

$\mathrm{CaSO}_{4} \cdot \mathrm{nH}_{2} \mathrm{O}+4 \mathrm{CO}\left(\mathrm{NH}_{2}\right)_{2}=\mathrm{CaSO}_{4} \cdot 4 \mathrm{CO}\left(\mathrm{NH}_{2}\right)_{2}+$ $\mathrm{nH}_{2} \mathrm{O}$

where: $\mathrm{n}=0,1 / 2,2$.

This adducts has lower hygroscopicity than urea and the nutritional effect of urea bound into the adduct form is retarded ${ }^{3,4}$. These properties are very important in damp climatic zones. Calcium sulphate and urea adduct can be prepared by various methods. One of them consists in different types of crystallization from urea water solution. Calcium sulphate can be introduced to the system in various forms, however, the best results were obtained with its dihydrate ${ }^{3,5,6}$. Other varieties of this method consist in the introduction of salts containing $\mathrm{Ca}^{2+}$ and $\mathrm{SO}_{4}{ }^{2-}$ ions to the urea solution or compounds such as $\mathrm{CaCO}_{3}$ or $\mathrm{CaO}$ to the mixture of urea and sulfuric acid. Calcium sulphate crystallizes in these cases in the adduct form ${ }^{6}$. According to literature reports $\mathrm{CaSO}_{4} \cdot 4 \mathrm{CO}\left(\mathrm{NH}_{2}\right)_{2}$ adduct can be formed in the reaction between the urea and calcium sulphate dihydrate or hemihydrate, mixed physically in the stoichiometic ratio, then left in air atmosphere of relative humidity $60-70 \%^{3,7}$. Another method of calcium sulphate and urea adduct preparation is melting a mixture of urea and calcium sulphates at various hydration levels. The best results were obtained when the mixture of urea and calcium sulphate dihydrate was melted ${ }^{6}$. Calcium sulphate and urea adduct were also prepared by grinding. We have noticed that calcium sulphate conversion into the adduct was growing, together with the grinding time. However, it was found that total conversion would require a relatively long grinding time. Compaction tests of the mixture prepared by grinding indicate that calcium sulphate conversion into the adduct decreases together with the growth of compaction pressure ${ }^{8}$.

\section{METHODS}

Only one literature report concerning calcium sulphate and urea adduct, describes a method for the measurement of calcium sulphate and urea conversion into the adduct form ${ }^{8}$. This method is questionable as the adduct is probably decomposed during the determination. That is why we decided to develop a simple method for measuring conversion in the studied system. Investigations were directed to find a solvent where free urea would be dissolved but not the one bound into the adduct form. The conducted search indicates that $n$-butanol meets the set requirements and a measurement method of urea conversion into the adduct form, which we used in our study, was proposed. In order to dissolve the unreacted urea, a sample was treated with n-butanol and then the liquid phase was separated from the sediment. Then the adduct, remaining in the sediment, was decomposed with water. When the liquid phase was separated from the deposit then the urea dissolved in water, was determined. Simultaneously, the total urea content in the sample was determined. Urea conversion into the adduct form can be calculated in the following way:

$\propto=\frac{\mathrm{CO}\left(\mathrm{NH}_{2}\right)_{2} \text { adduct }}{\mathrm{CO}\left(\mathrm{NH}_{2}\right)_{2} \text { total }} 100, \%$

A spectrophotometric method with p-DMABA (p(dimethyl)aminobenzaldehyde) was used for the determination of urea content'. Hardness of fertilizer granules prepared on the laboratory scale was measured with the ERWEKA TBH 20 apparatus. Every time $20-30$ granules of diameter $3.15-4.00 \mathrm{~mm}$ were used for the measurements.

The chemically pure compounds and those from commercial plants were used as raw materials for investigations. Phosphogypsums from Chemical Works „WIZÓW” S.A. and GZNF „FOSFORY” Ltd. were amongst the raw materials from commercial plants (Table 1).

\section{RESEARCH RESULTS}

Preparation tests of calcium sulphate and urea adduct by grinding, compaction and mixing of adduct components in the presence of physical water were conducted.

Grinding tests were carried out in an agate mill with a vibrating ball at the temperature of $20^{\circ} \mathrm{C}$. A weighed portion of reagents was ground and samples in the specified time 
Table 1. The chemical composition of phosphogypsums used for the investigations

\begin{tabular}{|c|l|c|c|}
\hline No. & Determination & $\begin{array}{c}\text { Phosphogypsum from Chemical } \\
\text { Works “Wizów" S.A. } \\
\text { [wt. \%] }\end{array}$ & $\begin{array}{c}\text { Phosphogypsum from GZNF } \\
\text { "Fosfory" Ltd. } \\
\text { [wt. \%] }\end{array}$ \\
\hline 1. & Calcination losses at $105^{\circ} \mathrm{C}$ & 19.21 & 15.05 \\
\hline 2. & Calcination losses at $400^{\circ} \mathrm{C}$ & 23.69 & 30.10 \\
\hline 3. & Calcination losses at $1000^{\circ} \mathrm{C}$ & 25.12 & 31.65 \\
\hline 4. & $\mathrm{SO}_{3}{ }^{*}$ & 43.17 & 39.96 \\
\hline 5. & $\mathrm{CaO}^{*}$ & 29.25 & 27.79 \\
\hline 6. & $\mathrm{P}_{2} \mathrm{O}_{5}{ }^{*}$ & 1.25 & 1.48 \\
\hline
\end{tabular}

Measured in wet product

Table 2. Urea conversion measured during an adduct preparation test by grinding

\begin{tabular}{|c|c|c|c|c|c|c|}
\hline \multirow{2}{*}{ No. } & Calcium sulphate form & \multirow{2}{*}{$\mathrm{CaSO}_{4}: \mathrm{CO}\left(\mathrm{NH}_{2}\right)_{2}$ mole ratio } & \multicolumn{3}{|c|}{ Urea conversion in time [\%] } & Induction time \\
\cline { 4 - 6 } & used in the reaction & & $10 \mathrm{~min}$ & $60 \mathrm{~min}$ & $180 \mathrm{~min}$ & \\
\hline 1. & $\mathrm{CaSO}_{4}$ (anhydrous) & $1: 4$ & 0.36 & 0.64 & 1.00 & - \\
\hline 2. & & $1: 2$ & 1.04 & 18.9 & 84.5 & $\sim 60$ \\
3. & $\mathrm{CaSO}_{4} \cdot 0.5 \mathrm{H}_{2} \mathrm{O}$ & $1: 4$ & 2.7 & 14.9 & 68.9 & $\sim 60$ \\
4. & & $1: 6$ & $1.2(1.8)$ & $26.6(39.8)$ & $51.9(77.9)$ & $\sim 30$ \\
\hline 5. & & $1: 2$ & 0.95 & 1.3 & 80.4 & $\sim 90$ \\
6. & $\mathrm{CaSO}_{4} \cdot 2 \mathrm{H}_{2} \mathrm{O}$ & $1: 4$ & 2.4 & 5.1 & 72.1 & $\sim 80$ \\
7. & & $1: 6$ & $1.2(1.8)$ & $4.2(6.3)$ & $53.5(80.2)$ & $\sim 60$ \\
\hline
\end{tabular}

The results in parentheses - without taking into consideration the urea excess

Table 3. Urea conversion measured during the tests of adduct preparation by the way of compaction

\begin{tabular}{|c|c|c|c|c|c|}
\hline \multirow{2}{*}{ No. } & $\begin{array}{c}\text { Calcium sulphate form used in the } \\
\text { reaction }\end{array}$ & 58.8 & 98.1 & \multicolumn{3}{|c|}{ Urea conversion [\%] at various compaction pressures [MPa] } \\
\cline { 3 - 6 } & $\mathrm{CaSO}_{4}$ & 0.95 & 1.36 & 0.88 & 294.2 \\
\hline 1. & $\mathrm{CaSO}_{4} \cdot 0.5 \mathrm{H}_{2} \mathrm{O}$ & 38.6 & 40.2 & 34.3 & 2.6 \\
\hline 2. & $\mathrm{CaSO}_{4} \cdot 2 \mathrm{H}_{2} \mathrm{O}$ & 44.3 & 46.3 & 42.1 & 35.3 \\
\hline 3. & $\begin{array}{c}\text { Ltd. } \\
\text { Ltrom GZNF "Fosfory" }\end{array}$ & 27.2 & 35.2 & 26.9 & 15.2 \\
\hline 4. & $\begin{array}{c}\text { Phosphogypsum } \\
5 .\end{array}$ & 24.6 & 32.3 & 40.0 & 38.5 \\
\hline
\end{tabular}

intervals were taken to determine the urea conversion into the adduct form. The analytically pure calcium sulphate: anhydrous, hemihydrated and dihydrated, ground below $0.1 \mathrm{~mm}$, mixed with urea in various ratios was used for the investigations (Table 2).

Very low urea conversion in the system with anhydrous calcium sulphate indicates low reactivity of this form of sulphate. After $180 \mathrm{~min}$ of grinding the conversion was only $1.0 \%$ (Tab.2). When the hydrated forms of calcium sulphate were used in the tests we noticed that the reagent mixture changed its consistency during grinding. In the beginning the reagent had a form of loose powder. After some time (induction period), different - depending on the used form calcium sulphate and the reagent mole ratio, the mixture particles started to agglomerate. This phenomenon was caused by urea displacement of water in the hydrate, which is proved by a sudden increase of conversion at that particular moment. The induction period was shorter in the case of grinding urea with calcium sulphate hemihydrate. We presume that the shorter induction period was caused by weaker water bonding in calcium sulphate hemihydrate. It was also discovered that the higher the mole ratio of urea to calcium sulphate dihydrate or hemihydrate is, the shorter the induction period occurs.

Mixtures of calcium sulphates from various sources and urea, at the $\mathrm{CaSO}_{4}: \mathrm{CO}\left(\mathrm{NH}_{2}\right)_{2}$ mole ratio 1:4, were placed in a steel mould of the $25 \mathrm{~mm}$ diameter and compacted with a hydraulic press. The moulded pieces were crushed, dried at the temperature of $105^{\circ} \mathrm{C}$ and then studied. Compaction tests of a mixture of urea and anhydrous calcium sulphate showed that also in these conditions this form of calcium sulphate demonstrated very low reactivity (Table 3 ). The adduct can be prepared by compaction using the hydrated forms of calcium sulphate but then urea conversion into the adduct does not exceed $50 \%$. Moreover, it was found that urea conversion decreased when compaction pressure was increased over 98 MPa. This phenomenon was also described by Kotuła and Nowak ${ }^{8}$.

While compaction of mixtures formed with phosphogypsums at high pressure, a disadvantageous phenomenon was observed, which consisted in the solution evolution from the sample being compacted. It was observed at the pressure over $98 \mathrm{MPa}$ for phosphogypsum from „Fosfory” and over $156 \mathrm{MPa}$ for phosphogypsum from "Wizów". When the formed pieces were taken out of the mould they were visibly wet and after drying crystals were formed on their surface. We presume that lower urea conversion at high pressure in the samples with phosphogypsum from „Fosfory” was caused by higher moisture content in this raw material. Higher moisture content causes higher solution evolution from a sample during compaction.

Because of the above phenomenon we made tests using the preliminary dried reagent mixtures (Table 4). Such treatment enables the preparation of a product that has better properties since it was found that urea conversion in such samples was higher. However, too high water content decrease in the mixture leads to lower urea conversion, which is caused by the difficulties in mass exchange between the reagents. The particles of the crushed moulded pieces of grain size about $4 \mathrm{~mm}$, were subjected to hardness tests (Table 4). The formed particles exhibited high hardness. It is worth noticing that the particles from sample No. 1 demonstrated lower hardness but the sample was prepared on the basis of phosphogypsum from GZNF and there was higher water content in the mixture subjected to compaction. However, the increased compaction pressure did not result in the higher hardness of the particles. 
Table 4. Urea conversion and the product particles' hardness measured during preparation tests of adduct by compaction

\begin{tabular}{|c|c|c|c|c|c|c|c|}
\hline \multirow[b]{2}{*}{ No. } & \multirow[b]{2}{*}{$\begin{array}{c}\text { Compaction } \\
\text { pressure, [MPa] }\end{array}$} & \multicolumn{3}{|c|}{ Phosphogypsum from GZNF "Fosfory" Ltd. } & \multicolumn{3}{|c|}{ Phosphogypsum from Chemical Works "Wizów" S.A } \\
\hline & & $\begin{array}{c}\text { Moisture } \\
\text { content in a } \\
\text { sample [wt. \%] }\end{array}$ & $\begin{array}{c}\text { Urea conversion } \\
{[\%]}\end{array}$ & $\begin{array}{l}\text { Hardness } \\
\text { [N/gran.] }\end{array}$ & $\begin{array}{l}\text { Moisture content in } \\
\text { a sample } \\
\text { [wt. \%] }\end{array}$ & $\begin{array}{c}\text { Urea conversion } \\
{[\%]}\end{array}$ & $\begin{array}{l}\text { Hardness } \\
\text { [N/gran.] }\end{array}$ \\
\hline 1. & 58.8 & 8.1 & 43.6 & 58.4 & 4.1 & 40.5 & 104.3 \\
\hline 2. & 58.8 & 2.5 & 40.1 & 128.8 & 1.9 & 37.1 & 103.4 \\
\hline 3. & 294.2 & 2.3 & 38.1 & 115.6 & 1.8 & 37.1 & 108.2 \\
\hline
\end{tabular}

Table 5. The properties of fertilizer granules of calcium sulphate and urea adduct type prepared on a laboratory scale

\begin{tabular}{|c|c|c|c|c|c|}
\hline \multirow{2}{*}{ No. } & \multirow{2}{*}{ Sulphuric raw material } & \multirow{2}{*}{$\begin{array}{c}\mathrm{CaSO}_{4}: \mathrm{CO}\left(\mathrm{NH}_{2}\right)_{2} \text { mole } \\
\text { ratio }\end{array}$} & \multirow{2}{*}{ Urea conversion [\%] } & \multicolumn{2}{|c|}{ Hardness [N/gran.] } \\
\hline & & & & Initial & After 3 months \\
\hline 1. & $\begin{array}{c}\text { Phosphogypsum from } \\
\text { Chemical Works "Wizów" } \\
\text { S.A. }\end{array}$ & $1: 4$ & 88.8 & 72.1 & 96.9 \\
\hline 2. & $\begin{array}{c}\text { Phosphogypsum from } \\
\text { Chemical Works "Wizów" } \\
\text { S.A. }\end{array}$ & $1: 2$ & 81.4 & 78.7 & 96.3 \\
\hline 3. & $\begin{array}{l}\text { Phosphogypsum from } \\
\text { GZNF "Fosfory" Ltd. }\end{array}$ & $1: 4$ & 85.6 & 75.5 & 93.0 \\
\hline
\end{tabular}

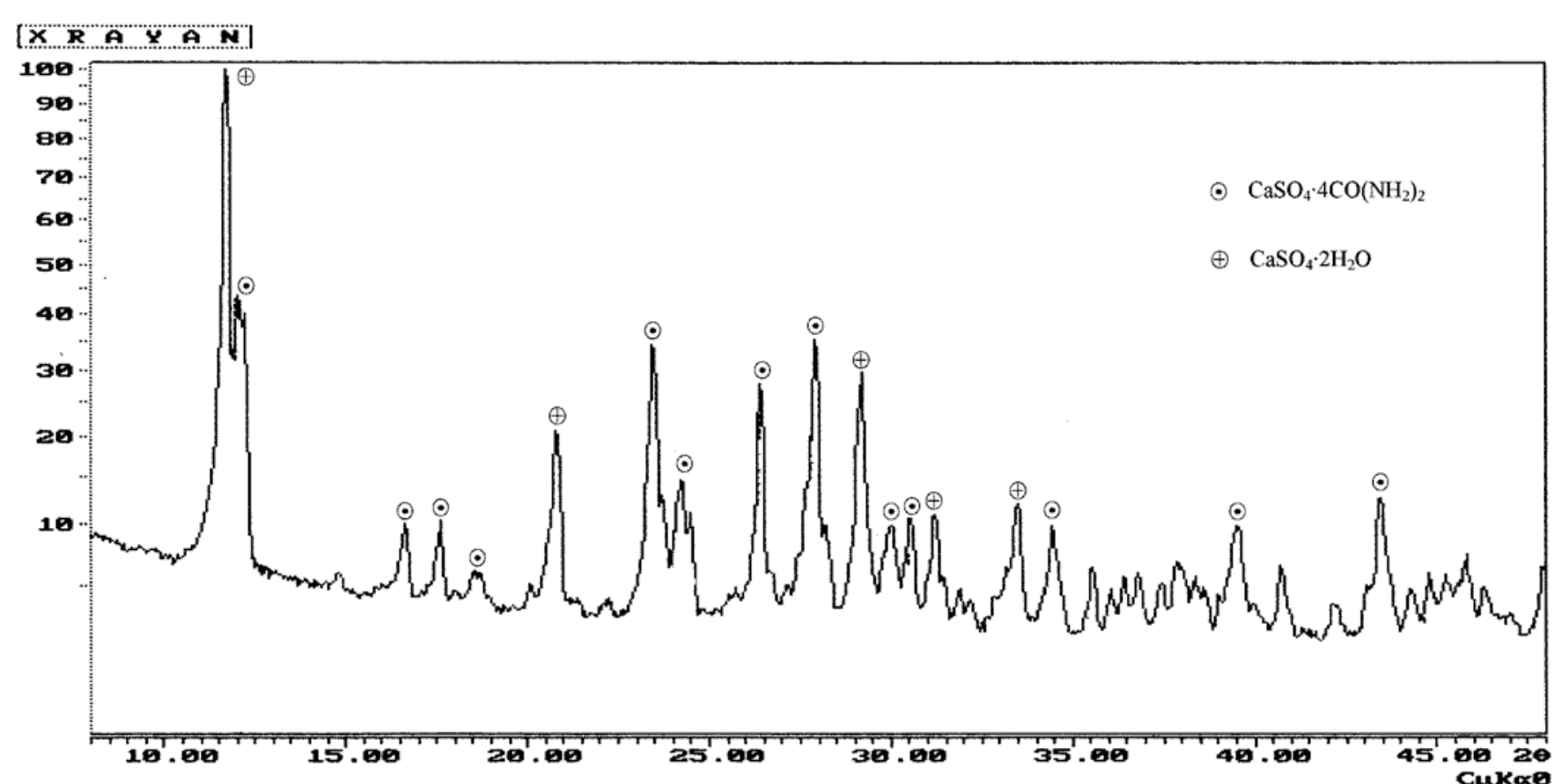

Figure 1. X-ray diffraction pattern of the fertilizer sample of calcium sulphate and the urea adduct type

The tests of calcium sulphate and urea adduct preparation by mixing the components in the presence of physical water were carried out and then the tests of the prepared mixture granulation in a screw granulator were conducted. Phosphogypsums from Chemical Works „Wizów” S.A. and GZNF „Fosfory” Ltd. were the source of calcium sulphate. The mixtures of phosphogypsum and urea at $\mathrm{CaSO}_{4}: \mathrm{CO}\left(\mathrm{NH}_{2}\right)_{2}$ mole ratios $=1: 4$ and 1:2 were mixed in a electric mixer for 10 minutes at the temperature of $20^{\circ} \mathrm{C}$. The prepared mixture of the thick paste consistency was granulated in a screw granulator. The prepared product threads of $3.5 \mathrm{~mm}$ diameter were cut into smaller pieces. In order to prevent particle caking they were covered with powder of partly dehydrated phosphogypsum. The granules were dried at the temperature of $105^{\circ} \mathrm{C}$ and then further studied. When mixing the raw materials we noticed that the mixture changed the colour when its consistency altered. In the first mixing phase the mixture of the moist crystals had a relatively freeflowing form. After about $300 \mathrm{~s}$ the mixture changed its consistency in a few seconds into a rather thick paste during the tests at $20^{\circ} \mathrm{C}$. The process was accompanied by a change of colour. In the case of the phosphogypsum from Wizów the colour changed from grey into white and in the case of phosphogypsum from GZNF - from dark brown to light brown. It can indicate that the initial induction period was followed by a sudden growth of the reaction rate. When the mixture temperature was increased to $60^{\circ} \mathrm{C}$ the induction period was decreased to $30 \mathrm{~s}$. After that time there was also a sudden change of the mixture consistency and colour.

The products prepared by the mixing method exhibited high urea conversion into the adduct form, even $90 \%$ (Tab. 5). The granules had high hardness increased during their storage. When the urea, containing fertilizers, are assessed it is important to determine their biuret content because this compound has phytofoxic effect. During the long (several hours) heating at the temperature of $105^{\circ} \mathrm{C}$ of the samples of the prepared calcium sulphate and urea adduct there was no marked increase of biuret content.

According to one literature report it is possible to prepare a calcium sulphate and urea adduct of the molecular formula: $\mathrm{CaSO}_{4} \cdot 2 \mathrm{CO}\left(\mathrm{NH}_{2}\right)_{2}{ }^{\mathbf{1 0}}$. We made an X-ray analysis of a fertilizer sample prepared from phosphogypsum and urea mixed at the $\mathrm{CaSO}_{4}: \mathrm{CO}\left(\mathrm{NH}_{2}\right)_{2}$ mole ratio $=1: 2$ (Fig.1). We expected such compound in the prepared fertilizer. However, 
the analysis demonstrated that $\mathrm{CaSO}_{4} \cdot 4 \mathrm{CO}\left(\mathrm{NH}_{2}\right)_{2}$ adduct was the main fertilizer component, beside calcium sulphate dihydrate.

\section{CONCLUSIONS}

Various methods of calcium sulphate and urea adduct preparation were tested using chemically pure compounds and those from commercial plants as raw materials. In order to conduct such investigations it was necessary to develop a method for measuring urea conversion into the adduct form because the one prepared in literature is questionable. The method for urea conversion measurement, developed for our study purposes, is based on the difference of the solubility of free urea and the one bound into the $\mathrm{CaSO}_{4} \cdot 4 \mathrm{CO}\left(\mathrm{NH}_{2}\right)_{2}$ adduct form in n-butanol.

It was found that calcium sulphate and urea adduct can be prepared by mixing but the high degree of urea conversion into the adduct form requires a relatively long time in such conditions. We noticed that during mixing there was an induction period after which the adduct formation rate increased substantially. It was found that calcium sulphate hemihydrate had the highest reactivity in relation to the urea on the basis of urea conversion and induction time measured in the tests of the adduct preparation by this method.

Fertilizers of calcium sulphate and adduct type having good physico-chemical properties can also be prepared by a compaction method. It is worth noticing that urea conversion into the adduct form in fertilizers prepared by this method does not exceed $50 \%$. Moreover, this method requires phosphogypsum that was initially dried to the moisture content below 15 wt.\%.

Laboratory scale tests of adduct type fertilizer preparation by intensive component mixing gave products of very good physico-chemical properties. High urea conversion into the adduct form in such fertilizers proves that this method can be used successfully for the preparation of $\mathrm{CaSO}_{4} \cdot 4 \mathrm{CO}\left(\mathrm{NH}_{2}\right)_{2}$ adduct. The granules of such fertilizers exhibit high hardness, which grows during their storage.

\section{LITERATURE CITED}

(1) Tengler S.: Niektóre międzycząsteczkowe połączenia mocznika ze związkami nieorganicznymi, Chemik, 1972, 8, 308.

(2) Durski Z.: Krystaliczne addukty mocznika ze związkami nieorganicznymi, Wiadomości. Chemiczne, 1971, 25, 829.

(3) Whittaker C., Lundstom F., Hendricks S.: Reaction between urea and gypsum, Industrial \& Engineering Chemistry, 1933, 11, 1280.

(4) Achard P., Schwob Y., Limousin L.: A new route for urea-superphosphate fertilizers, Phosphorus \& Potassium, 1994, 191, 27.

(5) Patent USA 2074880, 1937.

(6) Nagai S., Hara Z.: Studies on gypsum - urea or urea - calcium sulphate complex I, Journal of Society Chemical Industry Japan, Suppl. Bind., 1939, 42, 210.

(7) Nagai S., Miyake R., Studies on gypsum - urea or urea - calcium sulphate complex II, Journal of Society Chemical Industry Japan, Suppl. Bind., 1940, 43, 209.

(8) Kotuła E., Nowak R.: Czteromocznikan siarczanu wapnia - nawóz azotowo-siarkowo-wapniowy jako alternatywa utylizacji fosfogipsu, Prace Nauk. Politechniki Szczecińskiej, 1998, 547, ITN 5, 91.

(9) Maciaszek S.: Mocznik, WNT, Warszawa 1967.

(10) Patent USA 3976467, 1976. 